\title{
Blood/Brain Biomarkers of Inflammation After Stroke and Their Association With Outcome: From C-Reactive Protein to Damage-Associated Molecular Patterns
}

\author{
Alejandro Bustamante ${ }^{1}$ - Alba Simats ${ }^{1}$ - Andrea Vilar-Bergua ${ }^{1}$. \\ Teresa García-Berrocoso ${ }^{1}$ - Joan Montaner ${ }^{1}$
}

Published online: 18 August 2016

(C) The American Society for Experimental NeuroTherapeutics, Inc. 2016

\begin{abstract}
Stroke represents one of the most important causes of disability and death in developed countries. However, there is a lack of prognostic tools in clinical practice to monitor the neurological condition and predict the final outcome. Blood biomarkers have been proposed and studied in this indication; however, no biomarker is currently used in clinical practice. The stroke-related neuroinflammatory processes have been associated with a poor outcome in stroke, as well as with poststroke complications. In this review, we focus on the most studied blood biomarkers of this inflammatory processes, cytokines, and C-reactive protein, evaluating its association with outcome and complications in stroke through the literature, and performing a systematic review on the association of Creactive protein and functional outcome after stroke. Globally, we identified uncertainty with regard to the association of the evaluated biomarkers with stroke outcome, with little added value on top of clinical predictors such as age or stroke severity, which makes its implementation unlikely in clinical practice for global outcome prediction. Regarding poststroke complications, despite being more practical scenarios in which to make medical decisions following a biomarker prediction, not many studies have been performed, although there are now some candidates for prediction of poststroke infections. Finally, as potential new candidates, we reviewed the
\end{abstract}

Electronic supplementary material The online version of this article (doi:10.1007/s13311-016-0470-2) contains supplementary material, which is available to authorized users.

Joan Montaner

joan.montaner@vhir.org

1 Neurovascular Research Laboratory, Institut de Recerca, Hospital Universitari Vall d'Hebron (VHIR), Universitat Autónoma de Barcelona, Barcelona, Spain pathophysiological actions of damage-associated molecular patterns as triggers of the neuroinflammatory cascade of stroke, and their possible use as biomarkers.

Keywords Stroke $\cdot$ Inflammation $\cdot$ Biomarkers $\cdot$ Outcome $\cdot$ Cytokines $\cdot \mathrm{C}$-reactive protein $\cdot$ Alarmins

\section{Introduction}

Stroke currently represents one of the most important causes of death and disability worldwide. In fact, stroke causes 1 of every 20 deaths in USA, being the fifth leading cause of death. On average, someone dies of stroke every 4 min [1]. In-hospital mortality rates for ischemic stroke have been estimated to be between $11 \%$ and $15 \%$ [2]. However, beyond its lethality, stroke represents also one of the main causes of disability; approximately half of stroke survivors are disabled some months after stroke, and around $20 \%$ require institutionalization. Stroke is the third most common cause of disability worldwide, with $1.6 \%$ and $2.5 \%$ of disability-adjusted life years for ischemic and hemorrhagic stroke, respectively [3].

The main factors that account for this poor outcome after stroke in terms of disability and mortality, such as age or baseline stroke severity, are not modifiable. However, several circumstances may occur after stroke and may contribute to this poor outcome, representing a unique opportunity for researchers and clinicians for interventions to improve stroke outcome. Examples include neurological complications, such as brain edema or seizures, and systemic complications, such as infections or cardiac events. In fact, the modification of these circumstances, by early detection and treatment or prophylaxis in high-risk patients, might result in an improved stroke outcome [4]. 
The Biomarkers Definitions Working Group describes a biomarker as a characteristic that can be objectively measured and evaluated as an indicator of normal or pathologic biological processes, or pharmacologic responses to therapeutic interventions. Molecular biomarkers, detectable from blood, urine, or other biological fluids, may represent measurable indicators to predict the physiological states of a disease. However, despite many years of research in the field, no blood biomarker is currently used in stroke clinical practice, although the use of blood biomarkers to predict stroke outcome seems attractive for both clinicians and researchers, with several reviews published in recent years [5-7].

In this review, we will focus on how the neuroinflammatory processes triggered by stroke can be monitored through the measurement of blood biomarkers, and how these biomarkers might be used from a clinical point of view, both for global outcome prediction and also for prediction of poststroke complications. Specifically, we will focus on 3 different groups of biomarkers: cytokines and C-reactive protein (CRP), as the most studied inflammatory biomarkers in the stroke field and, as potential new candidates, damage-associated molecular patterns (DAMPs).

\section{Neuroinflammatory Cascade in Relation to Outcome and Complications of Stroke}

In the acute stroke setting, a lack of cerebral blood flow causing the interruption of oxygen and glucose supply to cerebral neurons and supporting cells results in massive cell necrosis within the infarct core [8]. In the surrounding area, cells are functionally impaired but still structurally intact, which makes that region potentially salvageable. If oxygen and glucose supplies are not restored, neuronal apoptosis processes are initiated, resulting in an increase of the lesion size.

Dying cells from both the ischemic core and the periinfarcted area release damage signals, known as DAMPs [9]. These signals activate the local microglia and peripheral leukocytes, resulting in a massive release of proinflammatory cytokines, upregulating the expression of leukocyte adhesion molecules and stimulating the synthesis of chemokines. Together with an increased blood-brain barrier (BBB) permeability, this response facilitates leukocyte infiltration into the brain compartment, to clear away the large amount of debris caused by cell death $[10,11]$. At later stages, the immune system also works to resolve postischemic inflammation, producing antiinflammatory mediators and removing the remaining inflammatory molecules.

Although the main reason for the activation of both resident and infiltrating immune cells is the facilitation of the clearance of debris in the infarcted area, it also results in deleterious effects on the ischemic brain. If the activation of peripheral leukocytes and microglia persist over time, the excess of inflammatory cytotoxic mediators will prolong the inflammatory response, increasing brain damage and contributing to secondary complications, such as edema or hemorrhagic transformation due to increased BBB permeability [12]. These effects are even worse in severe strokes, where the extension of the brain lesion is highly correlated with the strength of the neuroinflammatory reaction.

The hyperactivation of the peripheral immune cells may lead to exhaustion of mature leukocytes and the subsequent recruitment of immature leukocytes, a subpopulation unable to respond appropriately to brain injury [9]. The recruitment and expansion of this subpopulation causes lymphocytopenia, which significantly contributes to poststroke immunosuppression [13]. In addition, the excessive concentration of proinflammatory mediators can promote the release of glucocorticoids and catecholamines by the hypothalamic-pituitary-adrenal axis and the sympathetic nervous system. This results in the stimulation of anti-inflammatory pathways and the inhibition of proinflammatory mechanisms [14]. The rapid and inappropriate activation of these mechanisms also contributes to stroke-related immunosuppression, which enhances the risk of infection after cerebral ischemia. Moreover, the release of catecholamines by the hypothalamic-pituitary-adrenal axis might contribute to the development of cardiologic complications such as cardiac rhythm disorders or myocardial ischemia, especially when the right insula is affected [15]. Figure 1 summarizes the neuroinflammatory processes that brain ischemia generates, and their relationship with poststroke complications leading to poor outcome.

In addition to those phenomena occurring during the acute phase of stroke, it is known that chronic inflammation represents a crucial factor in the development and progression of atherosclerosis. The release of proinflammatory cytokines that happens in conditions such as rheumatoid arthritis, systemic autoimmune diseases, metabolic syndrome, or diabetes results in oxidative stress, insulin resistance, and endothelial dysfunction, therefore contributing to atherosclerosis [16]. Also, chronic infections are known to be associated with the risk of stroke. These lowgrade chronic inflammatory diseases such as periodontal disease or Chlamydia pneumoniae infections have been also associated with stroke, as they can increase the likelihood of platelet adhesion [17,18]. Therefore, chronic inflammation might act not just as a risk factor for stroke, but also as a triggering factor [19]. This background should be considered when measuring blood biomarkers during the acute episode, as these biomarkers are difficult to distinguish between acute, stroke-related elevations or chronically altered levels on inflammatory biomarkers. 
Fig. 1 Neuroinflammatory processes in brain ischemia and their relationship with poststroke complications leading to poor outcome DAMPs = damage-associated molecular patterns;

$\mathrm{HPA}=$ hypothalamic - pituitary adrenal axis;

SNS = sympathetic nervous system; BBB = blood-brain barrier

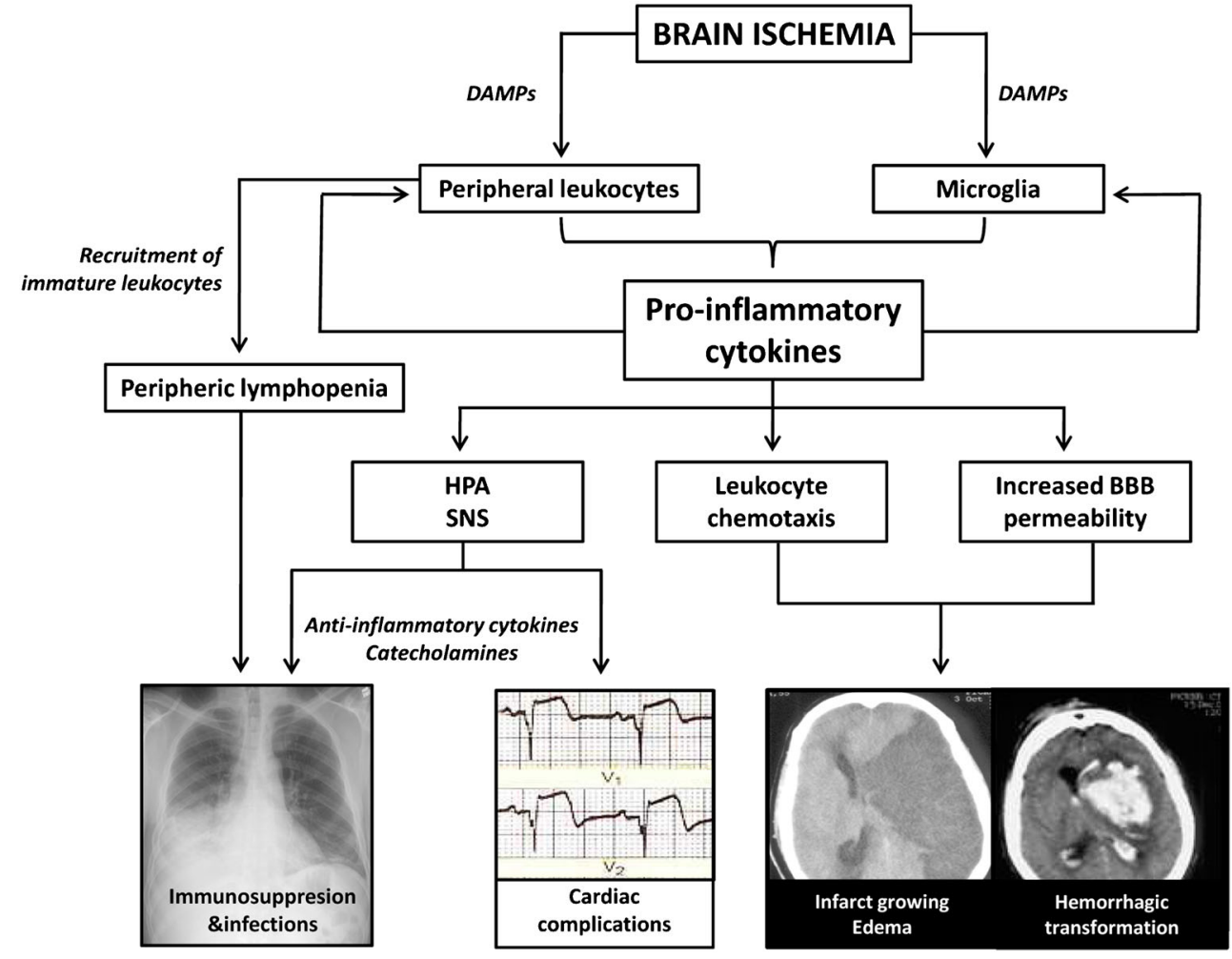

\section{Molecular Blood Markers of Inflammation and Stroke Outcome}

As shown in the previous section, neuroinflammation is related to some of the main factors related to stroke outcome, such as the extent of the ischemic brain injury (which is related to stroke severity), and poststroke complications. In this sense, associations between the inflammatory markers altered in the ischemic cascade and stroke outcome would be expected. The question remains on how these associations could be used by clinicians for stroke outcome improvement.

Blood stroke biomarkers can be either brain-specific markers, released from damaged tissue, or other more systemic indicators, such as those resulting from the inflammatory response at either local or peripheral level. In any case, levels of inflammatory markers in the peripheral blood usually reflect the peripheral response against stroke. Therefore, all molecular processes described in the previous sections should be taken into consideration for the detection of these candidate biomarkers, although the question of whether this inflammatory pattern is specifically reflecting a brain insult remains unanswered. Comparisons between patients with stroke and other brain-unrelated inflammatory diseases might help to clarify this issue. Inflammatory mediators such as cytokines, acute phase reactants, and some molecules involved in more specific pathways, such as cell adhesion molecules in chemotaxis or matrix metalloproteinases in BBB degradation, represent surrogate candidates to predict stroke outcome or its specific complications. In this review we will focus on cytokines and CRP as the candidates that have been more thoroughly explored in the literature and therefore the information about their association with stroke outcome should be more robust. Also, as a recent area of research and potential source for new biomarkers, we will focus on DAMPs or alarmins, mediators that are supposed to initiate the inflammatory response, being released from the cellular components of the infarct core and penumbra.

\section{Cytokines}

Cytokines are a family of pleiotropic polypeptides that regulate cell activation, proliferation, and differentiation [20]. In the normal brain, cytokines are barely detectable, as their receptors are expressed at very low levels. However, after an ischemic insult to the brain, cytokines are quickly and extensively upregulated [21], being responsible for both proinflammatory and anti-inflammatory mechanisms. Proinflammatory cytokines stimulates the inflammatory response, which could result in an amplification of the initial brain injury, as mentioned above. Interleukin (IL)-1 $\beta$, tumor necrosis factor (TNF), and IL-6 represent the main proinflammatory cytokines in stroke [21-23]. Anti-inflammatory cytokines inhibit the expression of proinflammatory cytokines, therefore reducing inflammation. Transforming growth factor (TGF) $-\beta$ and IL-10 represent the most studied anti-inflammatory cytokines after ischemic stroke at the experimental level [24]. However, 
the different effects of cytokines cannot be exclusively divided into pro- or anti-inflammatory, as some of them may exert neurotoxic, as well as neuroprotective, functions $[25,26]$. The balance between deleterious and beneficial effects of cytokines will depend on the physiological and biochemical context in the brain.

Cytokine measurement in acute stroke has been associated with stroke outcome, as well as the occurrence of some poststroke complications. Moreover, the time in which the measurement is performed might also result in different associations, as some biomarkers have been shown to be associated with different features at different time points. Table 1 shows an overview of the main studies exploring these associations.

\section{Proinflammatory cytokines}

IL-1 $\beta$ After stroke, IL-1 $\beta$ stimulates the expression of other proinflammatory mediators such as other cytokines and adhesion molecules, as well as the activation and proliferation of astrocytes and microglia [27]. Moreover, IL-1 $\beta$ induces edema formation and primes the endothelium for leukocyte adherence $[27,28]$. Beyond these neurotoxic effects, IL-1 $\beta$ also activates astrocytes to produce survival-promoting factors. Moreover, increases in IL-1 $\beta$ will lead to upregulation of IL-1 receptor antagonist (IL-1Ra), with opposite effects, being finally the balance between IL- $1 \beta$ and IL-1Ra more important for the global effect than IL-1 $\beta$ levels by itself [29].

In this sense, circulating levels of IL- $1 \beta$ and IL-1Ra might be good surrogate markers for outcome prediction. However, few clinical studies have explored their role as stroke biomarkers, resulting in controversial data. IL- $1 \beta$ levels were associated with poor long-term functional outcome in 1 study [30], while IL-1Ra levels have shown to be predictive of the development of poststroke infections, as well as its polymorphisms [31,32]. Moreover, recombinant IL-1Ra has been also explored from a therapeutic point of view, and was shown to reduce systemic inflammation in a placebo-controlled, phase II trial in patients with acute stroke [33].

TNF TNF is a pleiotropic cytokine with both neurotoxic and neuroprotective effects [34]. There is no consensus on the effect of TNF after ischemic stroke, but neurotoxic or neuroprotective effects will depend on several factors such as the extent and timing of microglial activation and the amount of TNF expression $[35,36]$. The main neurotoxic effects of TNF are potentiation of excitotoxicity by the inhibition of glutamate uptake and microglia activation [37], thereby promoting the production of neurotoxic mediators. TNF also promotes the apoptosis of endothelial cell, contributing to vasogenic edema and infiltration of circulatory inflammatory cells [38]. Regarding its neuroprotective effects,
TNF activates the repair of the brain microvasculature and mediates neuronal plasticity [25].

Clinical studies measuring TNF have shown inconsistent results. In fact, higher plasma TNF concentration has been found associated with poor outcome at 3 months when measured in the acute phase $[39,40]$. However, other studies have shown no differences regarding stroke outcome, despite similar time windows [41,42], nor poststroke infections [43,44]. The role of the circulating levels of TNF receptors 1 and 2 in outcome prediction is unclear so far, although levels of TNF receptor 1 have been described to predict recurrent vascular events after lacunar stroke [45].

IL-6 IL-6 is mainly produced not only by activated microglia, but also by astrocytes, neurons, and peripheral immune cells [46]. It helps to attract $\mathrm{T}$ lymphocytes to the brain, contributing to an exacerbation of the inflammatory response. However, IL-6-deficient mice do not show improved outcome after stroke, therefore putting into question its detrimental effects [47].

IL-6 has been one of the most studied inflammatory biomarkers in stroke patients, especially as a prognostic marker, although its role as a predictor of stroke risk has been also described [48]. In this sense, some studies have shown good associations between high IL-6 levels and short-term neurologic outcome [49], long-term functional outcome [50-52], or poststroke infections [53,54], although its additional predictive value over clinical information for outcome prediction has been questioned [41]. These data were confirmed by our group by performing both a literaturebased and individual participant data meta-analyses of 20 studies including 4389 patients. The results showed an independent association with long-term functional outcome but a very modest additional predictive value over clinical information over clinical variables such as age, sex, or stroke severity (a modest $1.5 \%$ increase in discrimination), in addition to publication bias [55].

\section{Anti-inflammatory cytokines}

TGF- $\beta$ From the different TGF- $\beta$ cytokines, only TGF- $\beta 1$, produced by activated microglia, and TGF- $\beta 2$, produced by astrocytes and neurons, are prominent after stroke [24]. TGF- $\beta$ reduces glial activation, decreases the expression of other cytokines, suppresses the release of oxygen- and nitrogen-derived products, promotes angiogenesis, and stimulates the release of IL-1Ra [56]. Its protective effects, however, are limited to the peri-infarcted area, as TGF- $\beta$ can inhibit apoptosis but not necrosis. Administration of TGF- $\beta$ before the induction of an ischemic insult has been shown to save neurons from cell death in mice [57]. However, not all studies agree on the beneficial effects of this cytokine, as a recent study reported that TGF- $\beta 1$ enhanced the expression of 
Table 1 Cytokines and outcome in stroke

\begin{tabular}{|c|c|c|c|}
\hline Cytokines & Role & Association with outcome & Association with complications \\
\hline IL-1 $\beta$ & Proinflammatory & Poor functional outcome [30] & Infections (not associated) [100] \\
\hline IL-1 Ra & $\begin{array}{l}\text { Anti- } \\
\text { inflammatory }\end{array}$ & Favorable functional outcome [33] & Infections $[31,32]$ \\
\hline IL-2 & Proinflammatory & - & Infections (not associated) [44] \\
\hline IL-4 & $\begin{array}{l}\text { Anti- } \\
\text { inflammatory }\end{array}$ & - & Infections (not associated) [44] \\
\hline IL-5 & $\begin{array}{l}\text { Anti- } \\
\text { inflammatory }\end{array}$ & - & Infections (not associated) [44] \\
\hline IL-6 & Proinflammatory & $\begin{array}{l}\text { Neurological deterioration } \\
{[39,40,101]} \\
\text { Poor functional outcome } \\
\quad[39-42,49-53,101-116] \\
\text { Poor functional outcome (not } \\
\text { associated) [117] }\end{array}$ & $\begin{array}{l}\text { Infections } \\
\quad[50,51,53,54,64,109,117] \\
\text { Edema (not associated) }[40,118] \\
\text { Hemorrhagic transformation (not } \\
\quad \text { associated) [40] }\end{array}$ \\
\hline IL-8 & Proinflammatory & - & Infections (not associated) [44] \\
\hline IL-10 & $\begin{array}{l}\text { Anti- } \\
\text { inflammatory }\end{array}$ & $\begin{array}{l}\text { Functional outcome (not associated) } \\
{[41,59]}\end{array}$ & $\begin{array}{l}\text { Infections: }[59,118] \\
\text { Infections (not associated) [44] } \\
\text { Edema (not associated) [119] }\end{array}$ \\
\hline IL-12a & Proinflammatory & - & Infections (not associated) [44] \\
\hline IL-13 & $\begin{array}{l}\text { Anti- } \\
\text { inflammatory }\end{array}$ & - & Infections [44] \\
\hline IFN- $\gamma$ & Proinflammatory & $\begin{array}{l}\text { Functional outcome (not associated) } \\
\text { [59] }\end{array}$ & $\begin{array}{l}\text { Infections [44] } \\
\text { Infections (not associated) [59] }\end{array}$ \\
\hline $\mathrm{TNF}$ & Proinflammatory & $\begin{array}{l}\text { Poor functional outcome }[39,40] \\
\text { Poor functional outcome (not } \\
\text { associated) }[41,42,59]\end{array}$ & $\begin{array}{l}\text { Infections (not associated) } \\
\quad[43,44,118] \\
\text { Edema (not associated) }[40,119]\end{array}$ \\
\hline
\end{tabular}

$\mathrm{IL}=$ interleukin; $\mathrm{IL}-1 \mathrm{Ra}=$ interleukin-1 receptor antagonist; $\mathrm{IFN}=$ interferon; $\mathrm{TNF}=$ tumor necrosis factor classical proinflammatory cytokines and enzymes that can disrupt the BBB [58]. To our knowledge, no clinical study has evaluated the role of TGF- $\beta$ in the prediction of outcome or complications of ischemic stroke.

IL-10 IL-10 is primary produced in activated microglia and astrocytes. It acts by inhibiting cytokine production and the expression of their receptors, as well as attenuating astrocytic activation. Some studies have evaluated the role of IL-10 as a biomarker for stroke outcome, without finding any relevant relationship [41,59]. Regarding poststroke infections, some studies showed higher IL-10 levels in patients who developed infections [43,60], although other studies did not find any association [44]. In this sense, although IL-10 might represent a potential candidate for this indication, more evidence is needed.

\section{CRP}

CRP is an acute-phase reactant, being part of the innate immune response. It is mainly produced in the liver, under the stimulation of IL-6, although peripheral lymphocytes and monocytes can also produce small amounts $[61,62]$. CRP binds to the phosphocholine expressed on the surface of dead or dying cells and some bacteria, activating the complement system and promoting phagocytosis by macrophages [63]. CRP levels rapidly increase as a result of stroke [64], although this acute-phase response occurs in response to a wide range of inflammatory conditions, reflecting the low specificity of CRP elevations. Regrettably, the ultimate role of CRP in acute stroke is not completely understood as it has anti-inflammatory and proinflammatory effects [65]. In addition to a higher stroke risk in population-based studies [66], elevated levels of CRP after stroke have been related to poor functional outcome and mortality [67-70], and also to the occurrence of poststroke infections [71], or brain edema [72]. Moreover, similar to other inflammatory markers, CRP levels were associated with infarct volume and stroke severity [50]. Despite its unspecific character, some studies have suggested that CRP elevations in stroke might reflect different phenomena depending on the time of rising, with early elevations being more related to stroke severity and late elevations with poststroke infections [70].

In order to investigate further the association of blood CRP levels and functional outcome after ischemic stroke, we performed a systematic review by searching the PubMed database up to March 2016, without language or other restrictions, for studies measuring CRP in patients with acute stroke and assessing long-term functional outcome. As search terms, we 
used a combination of medical subject heading terms and text words defining "stroke", "CRP", and "outcome". Additional references were obtained from www.stroke-biomarkers.com.

Inclusion criteria for the studies were 1) patients with ischemic stroke patients; 2) CRP blood levels measured during hospital admission, and 3) assessment of long-term (at least 1 month) functional outcome, measured with an accepted disability scale. Exclusion criteria were 1) unknown languages, 2) experimental studies with animal models or cell cultures, 3 ) nonoriginal studies (reviews, abstracts, letters, editorials, case reports), 4) studies including just hemorrhagic stroke or transient ischemic attacks, 5) stroke outcome reported just as neurological scores or death-survival rates, and 6) interventional studies or clinical trials.

Three different researchers performed the data extraction. The quality of the articles was assessed using a 15-point questionnaire for the evaluation of biomarker studies in stroke (available at www.stroke-biomarkers.com) [73]. All articles fulfilling the inclusion criteria were included in the metaanalysis independently of the quality score.

The initial PubMed search identified a total of 1497 studies. After the first screening, 40 studies met the inclusion criteria. An additional search on the website www.stroke-biomarkers. com identified 6 more studies. Thus, 46 studies were considered for systematic review (Fig. 2).

The quality of the articles was moderate (median 9 points; interquartile range $8-10$ points; range $3-12$ points). The most frequently missing points were sample size calculation (not reported by any study), reporting of blindness ( $8 / 46$ for clinical data collection and 10/46 for biomarker measurement), and use of previously established cut-offs for the biomarker (6/46). Quality points of each article are shown in detail in Supplementary material S2.

An overview of the studies reporting association between CRP and long-term functional outcome is given in Table 2. Sample size varied from 11 to $985[<100$ cases in $15(33 \%)$ studies]. From the included 46 studies, the modified Rankin score was the most used disability scale (40 studies). Only 26 studies reported baseline stroke severity, most of them by the National Institutes of Health Stroke Scale score. Time of longterm functional outcome assessment varied from 3 to 15 months. High-sensitivity assays measuring ultrasensitive CRP were used in 19 studies.

Elevated CRP levels were found to be associated with long-term functional outcome in all but 6 of the included studies $(87 \%)$. From the remaining 40 , the existence of an independent association by regression analysis was not assessed in 13 , while the remaining 27 did further adjustment by clinical covariates associated with stroke outcome. CRP was found to be an independent predictor of long-term functional outcome in 20 studies, while 7 of them found associations that were not further independent when adjusting for clinical covariates and/ or other blood biomarkers.
Despite the huge amount of literature on the association of CRP and outcome, we concluded that there is uncertainty regarding whether CRP levels might be an independent predictor of poor functional outcome in ischemic stroke. The wide variability in study design and data reporting represents the main limitation of this systematic review. Moreover, the additional predictive value of CRP over clinical variables, to our knowledge, has not been assessed in any study by using reclassification or discrimination tools [74]. All these data suggest that CRP is not a useful tool in clinical practice with which to predict stroke outcome, at least as a single biomarker. Further research should explore the particular association of CRP with poststroke complications. Moreover, these results show, again, that only using general inflammatory markers for predicting global outcome is not a good strategy, and we suggest dissecting further the different causes of bad outcome in order to identify specific markers for each of those conditions (infections, edema, etc.).

\section{New Candidates: DAMPs}

It remains unknown what exactly triggers the inflammatory response in the initial stages of cerebral ischemia. Candidates for this immune activation are DAMPs, or alarmins, such as heat shock proteins (Hsp) or high-mobility group box 1 (HMGB1) protein, which are released from dying cerebral tissue after stroke. The main receptors of DAMPs are located on immune cells, such as Toll-like receptors (TLR) and receptor for advanced glycation end products (RAGE), and their activation leads to the secretion of proinflammatory cytokines, generating an overall inflammatory environment $[9,75]$.

\section{HMGB1}

HMGB1 is a highly conserved nonhistone nuclear DNAbinding protein, expressed in most eukaryotic cells including neurons [76]. It has been described as a major autocrine and paracrine inflammatory signal in the context of inflammation $[77,78]$. In acute stroke, both passive release and active secretion have been described, being passive for neurons and astrocytes and active for activated astrocytes and microglia $[79,80]$. In the central nervous system, HMGB1 can bind to its putative receptors, including TLR2, TLR4, and RAGE. HMGB1RAGE binding results in the activation of inflammatory processes, leading to the overexpression of inflammatory mediators such as TNF, IL-1 $\beta$, intracellular adhesion molecule 1, vascular adhesion molecule 1, or E-selectin. Congruently, the inhibition of the HMGB1-RAGE pathway reduces inflammation and stroke size [77,81]. A recent study found that the cytokine-inducing isoform of HMGB1 was released from the ischemic brain in the hyperacute phase of stroke in mice and patients, and, furthermore, HMGB1-RAGE signaling 


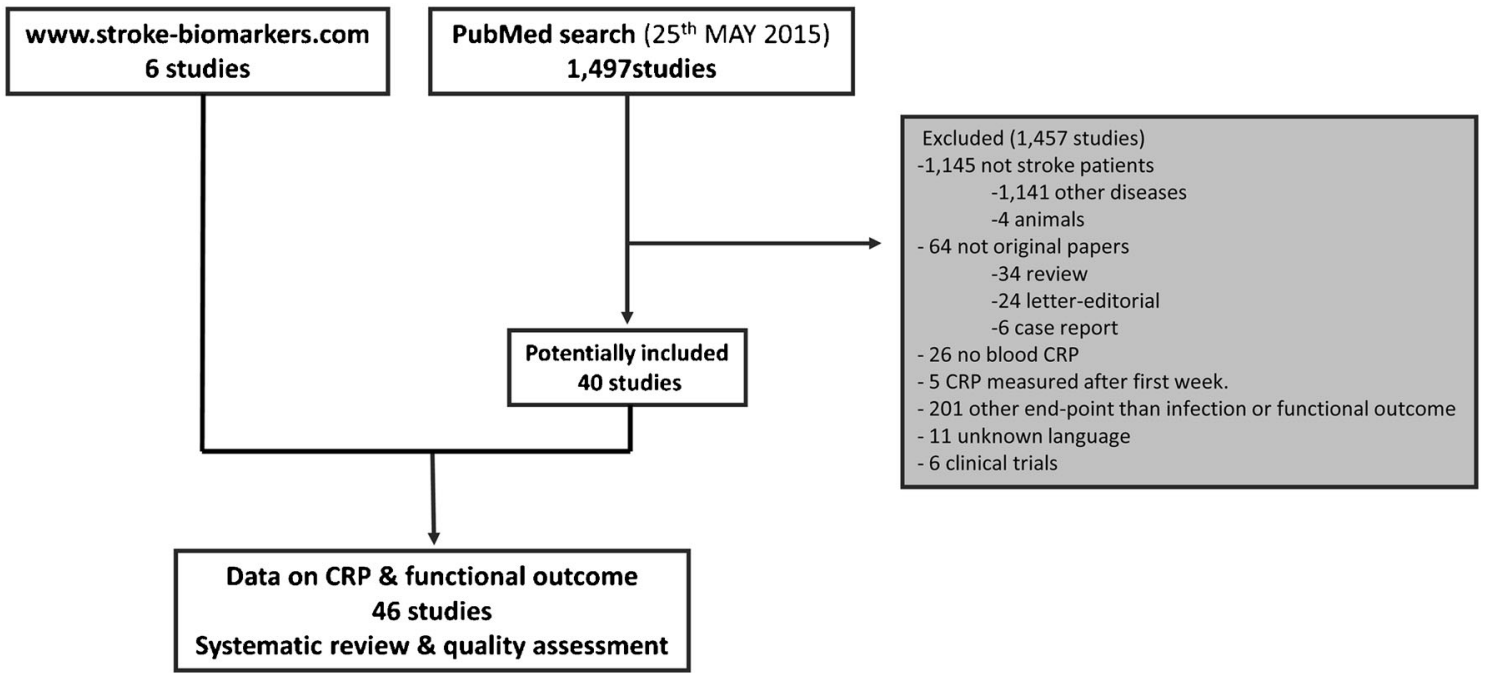

Fig. 2 Flow chart of the systematic review on C-reactive protein (CRP) and outcome after stroke

resulted in functional exhaustion of mature monocytes and lymphopenia, hallmarks of immune suppression after extensive ischemia [9]. These features introduce the HMGB1RAGE-mediated pathway as a key mechanism explaining the postischemic brain-immune interactions in relation to poststroke immunosuppression.

The association between HMGB1 and outcome after stroke has been assessed in some studies. In a study including 338 patients with stroke, plasma HMGB1 was reported as an independent predictor of 1-year clinical outcome, having a similar prognostic value to National Institutes of Health Stroke Scale score [82]. In an another study of 42 patients with ischemic stroke, increased plasma levels of HMGB1 were associated with a poor functional outcome, in addition to significantly higher levels of HMGB1, when compared with healthy controls [83]. An additional study found no association between HMGB1 and outcome, despite elevated levels that persisted for 30 days [84]. Regarding hemorrhagic stroke, a strong correlation was found between HMGB1 levels in cerebrospinal fluid and clinical outcome in 10 patients with Fisher-4 subarachnoid hemorrhage and acute hydrocephalus [85].

\section{Hsp}

Hsp play a crucial role in eukaryotes, acting as chaperones, preventing protein misfolding and aggregation [86]. The beststudied Hsp in the context of ischemia is Hsp70. Following stroke, Hsp70 is upregulated not only in neurons, but also in microglia, astrocytes, and endothelial cells [87]. Several in vivo and in vitro models have established neuroprotective effects of Hsp70 following stroke [88]. Even though Hsp70 seems to be involved in pathways that are both potentially protective and detrimental, such as apoptosis inhibition or immune system activation in stroke, its overall effects on final outcome seem to be protective. A recent study measured Hsp70 levels in plasma and lymphoid tissue of 46 patients with stroke and 16 healthy controls. Although plasma Hsp70 concentration at day 7 was similar in patients and controls, patients disclosed stronger immunoreactivity to Hsp70 in lymphoid tissue than controls, with most of the Hsp $70^{+}$cells being antigen presenting cells located in T-cell zones [89]. Beyond Hsp70, it has been reported that serum Hsp27 antibody levels measured $24 \mathrm{~h}$ after stroke onset were significantly higher than in controls but did not differ among patients with different stroke types and did not predict 6-month outcome [90]. Also, our group identified Hsp75 as a key protein in the inflammatory response that statins are able to block, in a proteomic study from ischemic rat brains, treated with simvastatin or placebo after embolic middle cerebral artery occlusion [91]. The study found relevantly lower Hsp75 levels in simvastatin-treated ischemic brains, and this reduction was also found in plasma samples from a clinical trial of simvastatin in acute stroke, in which simvastatin-treated patients showed lower levels than those treated with placebo [92].

\section{Other DAMPs}

Peroxiredoxin (Prx) family proteins are recently discovered DAMPs, expressed in different intracellular compartments. In neurons, their physiological functions include the maintenance of the redox homeostasis, by regulating levels of intracellular peroxide [93]. Following stroke, released Prx might also function as a DAMP, reversing the physiologically neuroprotective properties of DAMPs into detrimental functions [94]. In fact, the expression of Prx1 was found to be increased 
Table 2 Studies identified in the systematic review of C-reactive protein (CRP) and functional outcome in stroke

\begin{tabular}{|c|c|c|c|c|c|c|c|c|}
\hline Study & Material & $\mathrm{CRP} / \mathrm{hsCRP}$ & Assay & $\begin{array}{l}\text { First blood } \\
\text { collection }\end{array}$ & $\begin{array}{l}\text { Sample } \\
\text { size }\end{array}$ & $\begin{array}{l}\text { Functional } \\
\text { scale }\end{array}$ & $\begin{array}{l}\text { Time of } \\
\text { outcome } \\
\text { assessment }\end{array}$ & $\begin{array}{l}\text { Association } \\
\text { CRP outcome }\end{array}$ \\
\hline Vila et al. [120] & Serum & CRP & $\begin{array}{l}\text { Latex particle-enhanced } \\
\text { nephelometry }\end{array}$ & $<48 \mathrm{~h}$ & 41 & $\mathrm{mRS}$ & 6 months & Associated \\
\hline Anuk et al. [121] & Plasma & hsCRP & Nephelometer & $<24 \mathrm{~h}$ & 60 & $\mathrm{mRS}$ & $\begin{array}{l}8-12 \\
\text { months }\end{array}$ & Associated \\
\hline Winbeck et al. [122] & Serum & CRP & $\begin{array}{l}\text { Clinical chemistry } \\
\text { analyzer }\end{array}$ & $12-24 \mathrm{~h}$ & 127 & $\mathrm{mRS}$ & 1 year & $\begin{array}{l}\text { Independent } \\
\text { predictor }\end{array}$ \\
\hline Smith et al. [50] & Plasma & CRP & ELISA & $<24 \mathrm{~h}$ & 25 & $\mathrm{mRS}$ & 3 months & Associated \\
\hline Christensen et al. [123] & Unknown & CRP & - & $<24 \mathrm{~h}$ & 719 & $\mathrm{mRS}$ & 3 months & Associated \\
\hline $\begin{array}{l}\text { Waje-Andreassen } \\
\text { et al. [51] }\end{array}$ & Serum & $\begin{array}{l}\text { CRP } \\
\quad(\text { hsCRP }<10)\end{array}$ & ELISA & $<4 \mathrm{~h}$ & 11 & $\mathrm{BI}$ & 1 year & Not associated \\
\hline Hamidon et al. [124] & Serum & CRP & - & $<72 \mathrm{~h}$ & 49 & $\mathrm{BI}$ & 1 month & $\begin{array}{l}\text { Independent } \\
\text { predictor }\end{array}$ \\
\hline Masotti et al. [69] & Plasma & CRP & Nephelometric method & $<12 \mathrm{~h}$ & 196 & $\mathrm{mRS}$ & 1 month & Associated \\
\hline Montaner et al. [70] & Serum & hsCRP & Nephelometer & $<3 \mathrm{~h}$ & 143 & $\mathrm{mRS}$ & 3 months & Associated \\
\hline Efstathiou et al. [125] & Plasma & hsCRP & Immunonephelometric & $<24 \mathrm{~h}$ & 211 & $\mathrm{mRS}$ & 5 years & Associated \\
\hline Vibo et al. [126] & Plasma & CRP & $\begin{array}{l}\text { Immunoturbidimetric } \\
\text { assay }\end{array}$ & 1 week & 52 & $\mathrm{BI}$ & 15 months & Associated \\
\hline Geiger et al. [127] & Serum & CRP & Chemistry analyzer & $<24 \mathrm{~h}$ & 63 & $\mathrm{BI}$ & 12 months & Not associated \\
\hline Topakian et al. [128] & Unknown & CRP & $\begin{array}{l}\text { Particle-enhanced } \\
\text { immunoturbidimetry } \\
\text { assay }\end{array}$ & $<6 \mathrm{~h}$ & 111 & $\mathrm{mRS}$ & 3 months & $\begin{array}{l}\text { Associated, not } \\
\text { independent } \\
\text { predictor }\end{array}$ \\
\hline Ryu et al. [129] & Serum & CRP & - & $<24 \mathrm{~h}$ & 28 & BI & 6 months & Associated \\
\hline Welsh et al. [107] & Plasma & CRP & - & $<24 \mathrm{~h}$ & 180 & $\mathrm{mRS}$ & 1 month & $\begin{array}{l}\text { Independent } \\
\text { predictor }\end{array}$ \\
\hline $\begin{array}{l}\text { Sienkiewicz-Jarosz } \\
\text { et al. [130] }\end{array}$ & Serum & CRP & Immunoprecipitation & $<72 \mathrm{~h}$ & 54 & $\mathrm{mRS}$ & 3 months & $\begin{array}{l}\text { Independent } \\
\text { predictor }\end{array}$ \\
\hline Song et al. [131] & Serum & hsCRP & - & $<24 \mathrm{~h}$ & 417 & $\mathrm{mRS}$ & 3 months & Associated \\
\hline Varoglu et al. [132] & Serum & hsCRP & - & - & 33 & $\mathrm{mRS}$ & 1 month & Not associated \\
\hline Worthmann et al. [109] & Serum & hsCRP & $\begin{array}{l}\text { Clinical chemistry } \\
\text { analyzer }\end{array}$ & $6 \mathrm{~h}$ & 69 & $\mathrm{mRS}$ & 3 months & $\begin{array}{l}\text { Associated but } \\
\text { not } \\
\text { independent } \\
\text { predictor }\end{array}$ \\
\hline Brouns et al. [133] & Serum & CRP & Autoanalyzer & $\begin{array}{l}\text { Admission } \\
\text { (median } \\
4.3 \mathrm{~h})\end{array}$ & 149 & $\mathrm{mRS}$ & 3 months & Associated \\
\hline Song et al. [134] & Serum & hsCRP & - & $<24 \mathrm{~h}$ & 309 & $\mathrm{mRS}$ & 3 months & Associated \\
\hline Rajeshwar et al. [135] & Serum & hsCRP & ELISA & $<24 \mathrm{~h}$ & 581 & $\mathrm{mRS}$ & 3 months & $\begin{array}{l}\text { Independent } \\
\text { predictor }\end{array}$ \\
\hline Whiteley et al. [41] & Serum & hsCRP & Immunonephelometric & $<24 \mathrm{~h}$ & 270 & $\mathrm{mRS}$ & 3 months & $\begin{array}{l}\text { Associated but } \\
\text { not } \\
\text { independent } \\
\text { predictor }\end{array}$ \\
\hline Tsai et al. [136] & Serum & hsCRP & ELISA & $<48 \mathrm{~h}$ & 100 & $\mathrm{mRS}$ & 3 months & $\begin{array}{l}\text { Independent } \\
\text { predictor }\end{array}$ \\
\hline Lai et al. [137] & Plasma & hsCRP & ELISA & - & 269 & $\mathrm{mRS}$ & 3 months & $\begin{array}{l}\text { Independent } \\
\text { predictor }\end{array}$ \\
\hline Huang et al. [82] & Plasma & - & - & $<24 \mathrm{~h}$ & 338 & $\mathrm{mRS}$ & 1 year & $\begin{array}{l}\text { Associated but } \\
\text { not } \\
\text { independent } \\
\text { predictor }\end{array}$ \\
\hline Schulze et al. [84] & plasma & CRP & $\begin{array}{l}\text { Clinical chemistry } \\
\text { analyzer }\end{array}$ & $<72 \mathrm{~h}$ & 110 & $\mathrm{mRS}$ & 3 months & $\begin{array}{l}\text { Independent } \\
\text { predictor }\end{array}$ \\
\hline Zhang et al. [54] & Unknown & CRP & Chemiluminiscence & $<24 \mathrm{~h}$ & 106 & $\mathrm{mRS}$ & 1 month & $\begin{array}{l}\text { Independent } \\
\text { predictor }\end{array}$ \\
\hline
\end{tabular}


Table 2 (continued)

\begin{tabular}{|c|c|c|c|c|c|c|c|c|}
\hline Study & Material & CRP/hsCRP & Assay & $\begin{array}{l}\text { First blood } \\
\text { collection }\end{array}$ & $\begin{array}{l}\text { Sample } \\
\text { size }\end{array}$ & $\begin{array}{l}\text { Functional } \\
\text { scale }\end{array}$ & $\begin{array}{l}\text { Time of } \\
\text { outcome } \\
\text { assessment }\end{array}$ & $\begin{array}{l}\text { Association } \\
\text { CRP outcome }\end{array}$ \\
\hline Park et al. [138] & Serum & CRP & $\begin{array}{l}\text { Immunonephelometric } \\
\text { assay }\end{array}$ & $<12 \mathrm{~h}$ & 105 & $\mathrm{mRS}$ & 3 months & $\begin{array}{l}\text { Associated but } \\
\text { not } \\
\text { independent } \\
\text { predictor }\end{array}$ \\
\hline Gensicke et al. [139] & Blood & CRP & - & $<4.5 \mathrm{~h}$ & 257 & $\mathrm{mRS}$ & 3 months & $\begin{array}{l}\text { Associated but } \\
\text { not } \\
\text { independent } \\
\text { predictor }\end{array}$ \\
\hline Tiainen et al. [140] & Unknown & CRP & - & $<4.5 \mathrm{~h}$ & 985 & $\mathrm{mRS}$ & 3 months & $\begin{array}{l}\text { Independent } \\
\text { predictor }\end{array}$ \\
\hline Zhang et al. [141] & Plasma & CRP & Chemiluminiscence & $<72 \mathrm{~h}$ & 245 & $\mathrm{mRS}$ & 1 year & $\begin{array}{l}\text { Independent } \\
\text { predictor }\end{array}$ \\
\hline Tu et al. [142] & Serum & hsCRP & Enzyme cycling method & $<48 \mathrm{~h}$ & 189 & $\mathrm{mRS}$ & 3 months & $\begin{array}{l}\text { Independent } \\
\text { predictor }\end{array}$ \\
\hline Abubakar et al. [143] & Serum & CRP & $\begin{array}{l}\text { Particle-enhanced } \\
\text { immunoturbidimetric } \\
\text { assay }\end{array}$ & $<1$ week & 80 & $\mathrm{mRS}$ & 1 month & $\begin{array}{l}\text { Independent } \\
\text { predictor }\end{array}$ \\
\hline Tu et al. [144] & Unknown & - & - & $<48 \mathrm{~h}$ & 189 & $\mathrm{mRS}$ & 3 months & $\begin{array}{l}\text { Independent } \\
\text { predictor }\end{array}$ \\
\hline Kim et al. [145] & Blood & hsCRP & - & - & 604 & $\mathrm{mRS}$ & 3 months & Not associated \\
\hline Gong et al. [146] & Unknown & hsCRP & - & - & 977 & $\mathrm{mRS}$ & 1 year & $\begin{array}{l}\text { Independent } \\
\text { predictor }\end{array}$ \\
\hline Men et al. [147] & Serum & CRP & $\begin{array}{l}\text { Latex } \\
\text { immunoturbidimetric } \\
\text { assay }\end{array}$ & $<24 \mathrm{~h}$ & 308 & $\mathrm{mRS}$ & 1 month & $\begin{array}{l}\text { Independent } \\
\text { predictor }\end{array}$ \\
\hline Ozkan et al. [148] & Serum & hsCRP & $\begin{array}{l}\text { Ultrasensitive latex- } \\
\text { enhanced } \\
\text { immunoassay }\end{array}$ & $<48 \mathrm{~h}$ & 62 & FIM-FAS & 3 months & Not associated \\
\hline Taheraghdan et al. [149] & Serum & hsCRP & $\begin{array}{l}\text { Immunoturbidimetric } \\
\text { assay }\end{array}$ & $48 \mathrm{~h}$ & 102 & $\mathrm{mRS}$ & 3 months & Not associated \\
\hline Karlinski et al. [150] & Plasma & CRP & $\begin{array}{l}\text { Immunoturbidimetric } \\
\text { assay }\end{array}$ & $<24 \mathrm{~h}$ & 341 & $\mathrm{mRS}$ & 3 months & $\begin{array}{l}\text { Associated but } \\
\text { not } \\
\text { independent } \\
\text { predictor }\end{array}$ \\
\hline Potpara et al. [151] & Unknown & CRP & $\begin{array}{l}\text { Latex-enhanced } \\
\text { nephelometric }\end{array}$ & $<24 \mathrm{~h}$ & 240 & $\mathrm{mRS}$ & 1 month & $\begin{array}{l}\text { Independent } \\
\text { predictor }\end{array}$ \\
\hline Deng et al. [152] & Serum & hsCRP & Autoanalyzer & $<24 \mathrm{~h}$ & 378 & $\mathrm{mRS}$ & 3 months & $\begin{array}{l}\text { Independent } \\
\text { predictor }\end{array}$ \\
\hline Sezer et al. [153] & Serum & CRP & Autoanalyzer & $<24 \mathrm{~h}$ & 52 & $\mathrm{mRS}$ & 3 months & Associated \\
\hline Wang et al. [154] & Serum & hsCRP & Autoanalyzer & $<24 \mathrm{~h}$ & 376 & $\mathrm{mRS}$ & 1 year & $\begin{array}{l}\text { Independent } \\
\text { predictor }\end{array}$ \\
\hline Richard et al. [155] & Serum & CRP & ELISA & $<36 \mathrm{~h}$ & 75 & $\mathrm{mRS}$ & 3 months & $\begin{array}{l}\text { Independent } \\
\text { predictor }\end{array}$ \\
\hline
\end{tabular}

hsCRP = ultrasensitive CRP assay; mRS = modified Rankin scale; ELISA = enzyme-linked immunosorbent assay; BI = Barthel index; FIMFAS $=$ functional independence measure/functional ambulation scale (FAS)

in extracellular fluid from infarct core when compared with penumbra and the contralateral area in microdialysates from patients with ischemic stroke. Moreover, blood Prx1 levels were increased in patients with ischemic stroke compared with healthy controls [95]. In another study [96], circulating Prx5 levels were also measured in 98 patients with acute stroke, being inversely correlated with stroke severity and other inflammatory markers but not associated with outcome [96].

Besides the well-studied HMGB1, Hsp, and Prx, further DAMPs include S100 calcium-binding proteins A8 and A9 [97], myeloid-related proteins 8 and 14 [98], and coldinducible RNA-binding protein [99]. These have been 
reported to be capable of signaling via TLRs and/or RAGE. Nevertheless, the functional relevance of these molecules in stroke is so far unclear.

\section{Conclusions and Implications for Future Research}

From a theoretical point of view, given the close pathophysiological relationship between neuroinflammatory mediators and processes related to poor outcome in stroke, a role for inflammatory molecules as prognostic biomarkers could be expected. In this review, however, inconsistent results have been the rule for many of the explored molecules, as is the case for CRP and TNF. Additionally, for the majority of these molecules, their additional predictive value over clinical information, using statistical tools such as the integrated discrimination improvement index, remains unexplored. This step is extremely important, as has been shown for IL-6, probably one the most explored biomarkers, and with more consistent results. Despite the independent association of IL-6 with poor outcome, its additional discrimination over clinical variables was very modest, a fact that limits its use in clinical practice [55]. Regarding CRP, the systematic review showed a huge variability in the results, with some studies showing no further association when adjustment by covariates is performed, or even no association at the univariate level. With this background, an additional predictive value over highly explicative clinical variables such as stroke severity is difficult to expect.

The other key finding of this review is that the prediction of poststroke complications with inflammatory biomarkers has not been sufficiently explored through the literature. This is surprising, as a biomarker related to a specific process leading to poor outcome provides clinicians with more intuitive information on how to act, rather than a global prognostic approach. Future research in biomarkers to predict outcome in patients with stroke should focus on both: exploration of the additional predictive value of the biomarker over clinical information, and exploration of the predictive value for poststroke complications.

This review has focused on blood biomarkers. However, we cannot forget that other biomarkers of inflammation are becoming increasingly popular, such as those based on imaging of atherosclerosis. Although a review on imaging of inflammation is outside the scope of this article, future studies might explore whether a combination of biologic and imaging modalities is able to improve prediction. Beyond this issue, further efforts in the validation of inflammatory blood biomarkers should focus on the realization of large prospective, multicenter, international studies with the support of specific consortia such as the International Biomarker in Cerebrovascular Disease consortium (http://stroke-biomarkers.com/page.php?title=Network), as this type of study remains the best way in which to clarify the usefulness of a biomarker. As measurement of multiple biomarkers in large cohorts is expensive, selection of the best candidates via systematic reviews and meta-analyses could be useful as a preliminary step. Finally, interventional studies should be designed using biomarkers to make real decisions in the field, in order to assess their real impact in clinical practice.

Acknowledgments The Neurovascular Research Laboratory is part of the Spanish stroke research network INVICTUS (RD12/0014/0005) and is supported in stroke biomarkers research by Instituto de Salud Carlos III (grant number FIS PI15/354), co-financed by the European Regional Development Fund (FEDER). A.B. is supported by a Rio Hortega contract CM13/00265 from the Instituto de Salud Carlos III; A.S. is supported by a predoctoral fellowship (2015 FI B 00952) from the Agència de Gestió d'Ajuts Universitaris I de Recerca (AGAUR). We thank Josep Sánchez-Poblet and Sophie Guettier for kindly helping with the systematic review of $\mathrm{C}$-reactive protein.

Required Author Forms Disclosure forms provided by the authors are available with the online version of this article.

\section{References}

1. Mozaffarian D, Benjamin EJ, Go AS, et al; American Heart Association Statistics Committee and Stroke Statistics Subcommittee. Heart disease and stroke statistics-2016 update: a report from the American Heart Association. Circulation 2016; 133: e38-e360.

2. Johnston SC, Mendis S, Mathers CD. Global variation in stroke burden and mortality: estimates from monitoring, surveillance, and modeling. Lancet Neurol 2009; 8: 345-354.

3. Murray JL, Vos T, Lozano R, et al. Disability-adjusted life years (DALYs) for 291 diseases and injuries in 21 regions, 1990-2010: a systematic analysis for the Global Burden of Disease Study 2010. Lancet 2012; 380: 2197-2223.

4. Bustamante A, Garcia-Berrocoso T, Rodriguez N, et al. Ischemic stroke outcome: a review of the influence of post-stroke complications within the different scenarios of stroke care. Eur J Intern Med 2016; 29: 9-21.

5. Katan M, Elkind MSV. Inflammatory and neuroendocrine biomarkers of prognosis after ischemic stroke. Expert Rev Neurother 2011; 11: 225-239.

6. Whiteley W, Chong WL, Sengupta A, Sandercock P. Blood markers for the prognosis of ischemic stroke: a systematic review. Stroke 2009; 40: 380-389.

7. Bustamante A, Garcia-Berrocoso T, Llombart V, Simats A, Giralt D, Montaner J. Neuroendocrine hormones as prognostic biomarkers in the setting of acute stroke: overcoming the major hurdles. Expert Rev Neurother 2014; 14: 1391-1403.

8. Mehta SL, Manhas N, Raghubir R. Molecular targets in cerebral ischemia for developing novel therapeutics. Brain Res 2007; 54: 34-66.

9. Liesz A, Dalpke A, Mracsko E, et al. DAMP signaling is a key pathway inducing immune modulation after brain injury. $\mathrm{J}$ Neurosci 2015; 35: 583-598

10. Fumagalli S, Perego C, Pischiutta F, Zanier ER, De Simoni MG. The ischemic environment drives microglia and macrophage function. Front Neurol 2015; 6: 1-19.

11. Li L, Lundkvist A, Andersson D, et al. Protective role of reactive astrocytes in brain ischemia. J Cereb Blood Flow Metab 2008; 28; 468-481. 
12. Lakhan SE, Kirchgessner A, Hofer M. Inflammatory mechanisms in ischemic stroke: therapeutic approaches. J Transl Med 2009; 11: 1-11.

13. Liesz A, Hu X, Kleinschnitz C, Offner H. Functional role of regulatory lymphocytes in stroke: facts and controversies. Stroke 2015; 46: 1422-1430.

14. Esmaeili A, Dadkhahfar S, Fadakar K, Rezaei N. Post-stroke immunodeficiency: effects of sensitization and tolerization to brain antigens. Int Rev Immunol 2012; 31: 396-409.

15. Colivicchi F, Bassi A, Santini M, Caltagirone C. Cardiac autonomic derangement and arrhythmias in right-sided stroke with insular involvement. Stroke 2004; 35: 2094-2098.

16. Ozbalkan Z, Efe C, Cesur M, et al. An update on the relationships between rheumatoid arthritis and atherosclerosis. Atherosclerosis 2010; 212: 377-382.

17. Elkind MS, Lin IF, Grayston JT, Sacco RL. Chlamydia pneumoniae and the risk of first ischemic stroke. Stroke 2000; 31: 1521-1525.

18. Joshipura KJ. The relationship between oral conditions and ischemic stroke and peripheral vascular disease. J Am Dent Assoc 2002; 133: 23S-30S.

19. Das S, Ghosh KC, Pulai S, Pulai D, Bhar D, Gangopadhyay PK. Systemic infection and inflammation as trigger factors of ischemic stroke. Ann Neurosci 2011; 18: 17-20.

20. Zhao B, Schwartz JP. Involvement of cytokines in normal CNS development and neurological diseases: recent progress and perspectives. J Neurosci Res 1998; 52: 7-16.

21. Wang Q, Tang XN, Yenari MA. The inflammatory response in stroke. J Neuroimmunol 2007; 184: 53-68.

22. Hossmann KA. Pathophysiology and therapy of experimental stroke. Cell Mol Neurobiol. 2006; 26: 1057-1083.

23. Lai AY, Todd KG. Microglia in cerebral ischemia: molecular actions and interactions. Can J Physiol Pharmacol 2006; 84: 49-59.

24. Vitkovic L, Maeda S, Sternberg E. Anti-inflammatory cytokines: expression and action in the brain. Neuroimmunomodulation 2001; 9: 295-312.

25. Sriram K, O'Callaghan JP. Divergent roles for tumor necrosis factor-alpha in the brain. J Neuroimmune Pharmacol 2007; 2: 140-153.

26. Simats A, García-Berrocoso T, Montaner J. Neuroinflammatory biomarkers: from stroke diagnosis and prognosis to therapy. Biochim Biophys Acta 2016; 1862: 411-424.

27. Simi A, Tsakiri N, Wang P, Rothwell NJ. Interleukin-1 and inflammatory neurodegeneration. Biochem Soc Trans 2007; 35: 11221126.

28. del Zoppo GJ. Inflammation and the neurovascular unit in the setting of focal cerebral ischemia. Neuroscience 2009; 158: 972982.

29. Rothwell N. Interleukin-1 and neuronal injury: mechanisms, modification, and therapeutic potential. Brain Behav Immun 2003; 17: 152-157.

30. Protopsaltis J, Kokkoris S, Korantzopoulos P, et al. Prediction of long-term functional outcome in patients with acute ischemic nonembolic stroke. Atherosclerosis 2009; 203: 228-235.

31. Tanzi P, Cain K, Kalil A, et al. Post-stroke infection: a role for IL1ra? Neurocrit Care 2011; 14: 244-252.

32. Becker KJ, Dankwa D, Lee R, et al. Stroke, IL-1ra, IL1RN, infection and outcome. Neurocrit Care 2014; 21: 140-146.

33. Emsley HC, Smith CJ, Georgiou RF, et al. A randomised Phase II study of interleukin-1 receptor antagonist in acute stroke patients. J. Neurol Neurosurg Psych 2005; 76: 1366-1372.

34. Pan W, Kastin AJ. Tumor necrosis factor and stroke: role of the blood brain barrier. Prog Neurobiol 2007; 83: 363-374.

35. Gregersen R, Lambertsen K, Finsen B. Microglia and macrophages are the major source of tumor necrosis factor in permanent middle cerebral artery occlusion in mice. J Cereb Blood Flow Metab 2000; 20: 53-65.

36. Sharp FR, Lu A, Tang Y, Millhorn DE. Multiple molecular penumbras after focal cerebral ischemia. J Cereb Blood Flow Metab 2000; 20: 1011-1032.

37. Zou JY, Crews FT. TNF alpha potentiates glutamate neurotoxicity by inhibiting glutamate uptake in organotypic brain slice cultures: neuroprotection by NF kappa B inhibition. Brain Res 2005; 1034: 11-24.

38. Christov A, Ottman JT, Grammas P. Vascular inflammatory, oxidative and protease-based processes: implications for neuronal cell death in Alzheimer's disease. Neurol Res 2004; 26: 540-546.

39. Castellanos M, Castillo J, Garcia MM et al. Inflammationmediated damage in progressing lacunar infarctions: a potential therapeutic target. Stroke 2002; 33: 982-987.

40. Rodríguez JA, Sobrino T, Orbe J, et al. proMetalloproteinase-10 is associated with brain damage and clinical outcome in acute ischemic stroke. J Thromb Haemost 2013; 11: 1464-1473.

41. Whiteley W, Wardlaw J, Dennis M, et al. The use of blood biomarkers to predict poor outcome after acute transient ischemic attack or ischemic stroke. Stroke 2012; 43: 86-91.

42. Rodríguez-Yáñez M, Castellanos M, Sobrino T, et al. Interleukin10 facilitates the selection of patients for systemic thrombolysis. BMC Neurol 2013; 13: 62.

43. Chamorro A, Amaro S, Vargas M, et al. Catecholamines, infection, and death in acute ischemic stroke. J Neurol Sci 2007; 252: 29-35.

44. Salat D, Penalba A, García-Berrocoso T, et al. Immunological biomarkers improve the accuracy of clinical risk models of infection in the acute phase of ischemic stroke. Cerebrovasc Dis 2013; 35: $220-227$

45. Boehme AK, McClure LA, Zhang Y, et al. Inflammatory markers and outcomes after lacunar stroke: levels of inflammatory markers in treatment of stroke study. Stroke 2016; 47: 659-667.

46. Legos JJ, Whitmore RG, Erhardt JA, Parsons AA, Tuma RF, Barone FC. Quantitative changes in interleukin proteins following focal stroke in the rat. Neurosci Lett 2000; 282: 189-192.

47. Clark WM, Rinker LG, Lessov NS, et al. Lack of interleukin-6 expression is not protective against focal central nervous system ischemia. Stroke. 2000; 31: 1715-1720.

48. Castillo J, Alvarez-Sabín J, Martínez-Vila E, et al; MITICO Study Investigators. Inflammation markers and prediction of post-stroke vascular disease recurrence: the MITICO study. J Neurol 2009; 256: 217-224

49. Vila N, Castillo J, Dávalos A, Chamorro A. Proinflammatory cytokines and early neurological worsening in ischemic stroke. Stroke 2000; 31: 2325-2329.

50. Smith CJ, Emsley H, Gavin CM, et al. Peak plasma interleukin-6 and other peripheral markers of inflammation in the first week of ischaemic stroke correlate with brain infarct volume, stroke severity and long-term outcome. BMC Neurol 2004; 4: 2.

51. Waje-Andreassen U, Krakenes J, Ulvestad E, et al. IL-6: an early marker for outcome in acute ischemic stroke. Acta Neurol Scand 2005; 111; 360-365.

52. Orion D, Schwammenthal Y, Reshef T, et al. Interleukin-6 and soluble intercellular adhesion molecule- 1 in acute brain ischaemia. Eur J Neurol 2008; 15: 323-328.

53. Wartenberg KE, Stoll A, Funk A, Meyer A, Schmidt JM, Berrouschot J. Infection after acute ischemic stroke: risk factors, biomarkers, and outcome. Stroke Res Treat 2011; 2011: 830614.

54. Zhang X, Wang F, Zhang Y, Ge Z. Risk factors for developing pneumonia in patients with diabetes mellitus following acute ischaemic stroke. J Int Med Res 2012; 40: 1860-1865.

55. Bustamante A, Sobrino T, Giralt D, et al. Prognostic value of blood interleukin- 6 in the prediction of functional outcome after 
stroke: a systematic review and meta-analysis. J Neuroimmunol 2014; 274: 215-224.

56. Pantoni L, Sarti C, Inzitari D. Cytokines and cell adhesion molecules in cerebral ischemia: experimental bases and therapeutic perspectives. Arterioscler Thromb Vasc Biol 1998; 18: 503-513.

57. Ma M, Ma Y, Yi X, et al. Intranasal delivery of transforming growth factor-betal in mice after stroke reduces infarct volume and increases neurogenesis in the subventricular zone. BMC Neurosci 2008; 9: 117

58. Rustenhoven J, Aalderink M, Scotter EL, et al. TGF-beta1 regulates human brain pericyte inflammatory processes involved in neurovasculature function. J Neuroinflammation 2016; 13: 37.

59. Urra X, Cervera A, Obach V, Climent N, Planas AM, Chamorro A. Monocytes are major players in the prognosis and risk of infection after acute stroke. Stroke 2009; 40: 1262-1268.

60. Worthmann H, Tryc AB, Dirks M, et al. Lipopolysaccharide binding protein, interleukin-10, interleukin-6 and C-reactive protein blood levels in acute ischemic stroke patients with post-stroke infection. J Neuroinflammation 2015; 12: 13.

61. Kuta AE, Baum LL. C-reactive protein is produced by a small number of normal human peripheral blood lymphocytes. J Exp Med 1996; 164: 321-326.

62. Yasojima K, Schwab C, McGeer EG, McGeer PL. Generation of C-reactive protein and complement components in atherosclerotic plaques. Am J Pathol 2001; 158: 1039-1051.

63. Pepys MB, Hirschfield GM. C-reactive protein: a critical update. J Clin Invest 2003; 111: 1805-1812.

64. Emsley HC, Smith CJ, Gavin CM, et al. An early and sustained peripheral inflammatory response in acute ischaemic stroke: relationships with infection and atherosclerosis. J Neuroimmunol 2003; 139: 93-101.

65. Di Napoli M, Schwaninger M, Cappelli R, et al. Evaluation of Creactive protein measurement for assessing the risk and prognosis in ischemic stroke: a statement for health care professionals from the CRP Pooling Project members. Stroke 2005; 36: 1316-1329.

66. Ballantyne CM, Hoogeveen RC, Bang H, et al. Lipoproteinassociated phospholipase A2, high-sensitivity C-reactive protein, and risk for incident ischemic stroke in middle-aged men and women in the Atherosclerosis Risk in Communities (ARIC) study. Arch Intern Med 2005; 165: 2479-2484.

67. Elkind MS, Tai W, Coates K, Paik MC, Sacco RL. Highsensitivity C-reactive protein, lipoprotein-associated phospholipase A2, and outcome after ischemic stroke. Arch Intern Med 2006; 166: 2073-2080.

68. Di Napoli M, Papa F, Bocola V. C-reactive protein in ischemic stroke: an independent prognostic factor. Stroke 2001; 32: 917 924.

69. Masotti L, Ceccarelli E, Forconi S, Cappelli R. Prognostic role of $\mathrm{C}$-reactive protein in very old patients with acute ischaemic stroke. J Intern Med 2005; 258: 145-152.

70. Montaner J, Fernandez-Cadenas I, Molina CA et al. Poststroke Creactive protein is a powerful prognostic tool among candidates for thrombolysis. Stroke 2006; 37: 1205-1210.

71. Molnar T, Papp V, Banati M, et al. Relationship between Creactive protein and early activation of leukocytes indicated by leukocyte antisedimentation rate (LAR) in patients with acute cerebrovascular events. Clin Hemorheol Microcirc 2010; 44: 183192.

72. Modrego PJ, Boned B, Berlanga JJ, Serrano M. Plasmatic B-type natriuretic peptide and $\mathrm{C}$-reactive protein in hyperacute stroke as markers of CT-evidence of brain edema. Int J Med Sci 2008; 5: 18 23.

73. García-Berrocoso T, Giralt D, Bustamante A, et al. B-type natriuretic peptides and mortality after stroke: a systematic review and meta-analysis. Neurology 2013; 81: 1976-1985.
74. Pencina MJ, D'Agostino RB Sr, D'Agostino RB Jr, Vasan RS. Evaluating the added predictive ability of a new marker: from area under the ROC curve to reclassification and beyond. Stat Med 2008; 27: 157-172.

75. Gelderbloma M, Sobeyb CG, Kleinschnitzc C, Magnusa T. Danger signals in stroke. Ageing Res Rev; 2015; 24: 77-82.

76. Lotze MT, Tracey KJ. High-mobility group box 1 protein (HMGB1): nuclear weapon in the immune arsenal. Nat Rev Immunol 2005; 5: 331-342.

77. Kim JB. HMGB1, a novel cytokine-like mediator linking acute neuronal death and delayed neuroinflammation in the postischemic brain. J Neurosci 2006; 26: 6413-6421.

78. Qiu J, Nishimura M, Wang Y, et al. Early release of HMGB-1 from neurons after the onset of brain ischemia. J Cereb Blood Flow Metab 2008; 28: 927-938.

79. Bonaldi T, Talamo F, Scaffidi P, et al. Monocytic cells hyperacetylate chromatin protein HMGB1 to redirect it towards secretion. EMBO J 2003; 22: 5551-5560.

80. Semino C, Angelini G, Poggi A, Rubartelli A. NK/iDC interaction results inIL-18 secretion by DCs at the synaptic cleft followed by NK cell activation and release of the DC maturation factor HMGB1. Blood 2005; 106: 609-616.

81. Tang SC, Arumugam TV, Xu X, et al. Pivotal role for neuronal Toll-like receptors in ischemic brain injury and functional deficits. Proc Natl Acad Sci U S A 2007; 104: 13798-13803.

82. Huang JM, Hu J, Chen N, Hu ML. Relationship between plasma high-mobility group box-1 levels and clinical outcomes of ischemic stroke. J Crit Care 2013; 28: 792-797.

83. Sapojnikova N, Kartvelishvili T, Asatiani T, et al. Correlation between MMP-9 and extracellular cytokine HMGB1 in prediction of human ischemic stroke outcome. Biochim Biophys Acta 2014; 1842: 1379-1384.

84. Schulze J, Zierath D, Tanzi P, et al. Severe stroke induces longlasting alterations of high-mobility group box 1 . Stroke $2013 ; 44$ : 246-248.

85. Sokół B, Woźniak A, Jankowski R, et al. HMGB1 level in cerebrospinal fluid as a marker of treatment outcome in patients with acute hydrocephalus following aneurysmal subarachnoid hemorrhage. J Stroke Cerebrovasc Dis 2015; 24: 1897-1904.

86. Bukau B, Horwich AL. The Hsp70 and Hsp60 chaperone machines. Cell 1998; 92: 351-366.

87. Kim JY, Yenari MA. The immune modulating properties of the heat shock proteins after brain injury. Anat Cell Biol 2013; 46: 1-7.

88. Sharp FR, Zhan X, Liu DZ. Heat shock proteins in the brain: role of Hsp70, Hsp 27, and HO-1 (Hsp32) and their therapeutic potential. Transl Stroke Res 2013: 4; 685-692.

89. Gómez-Choco M, Doucerain C, Urra X, Planas AM, Chamorro A. Presence of heat shock protein 70 in secondary lymphoid tissue correlates with stroke prognosis. J Neuroimmunol 2014; 270: 67-74.

90. Azarpazhooh MR, Mobarra N, Parizadeh SM, et al. Serum highsensitivity C-reactive protein and heat-shock protein 27 antibody titers in patients with stroke and 6-month prognosis. Angiology 2010; 61: 607-612.

91. Campos-Martorell M, Salvador N, Monge M, et al. Brain proteomics identifies potential simvastatin targets in acute phase of stroke in a rat embolic model. J Neurochem 2014; 130: 301-312.

92. Montaner J, Chacón P, Krupinski J, et al. Simvastatin in the acute phase of ischemic stroke: a safety and efficacy pilot trial. Eur J Neurol 2008; 15: 82-90.

93. Hanschmann AM, Godoy JR, Berndt C, Hudemann C, Lillig CH. Thioredoxins, glutaredoxins, and peroxiredoxins-molecular mechanisms and health significance: from cofactors to antioxidants to redox signaling. Antioxid Redox Signaling 2013; 19: 1539-1605. 
94. Shichita T, Hasegawa E, Kimura A, et al. Peroxiredoxin family proteins are key initiators of post-ischemic inflammation in the brain. Nat Med 2012; 18: 911-917.

95. Dayon L, Turck N, García-Berrocoso T, Walter N, Burkhard PR, Vilalta A, et al. Brain extracellular fluid protein changes in acute stroke patients. Proteome Res 2011; 10: 1043-1051.

96. Kunze A, Zierath D, Tanzi P, Cain C, Becker K. Peroxiredoxin 5 (PRX5) is correlated inversely to systemic markers of inflammation in acute stroke. Stroke 2014; 45: 608-610.

97. Foell D, Wittkowski H, Vogl T, Roth J. S100 proteins expressed in phagocytes: a novel group of damage-associated molecular pattern molecules. J Leukoc Biol 2007; 81: 28-37.

98. Pruenster M, Kurz AR, Chung KJ, et al. Extracellular MRP8/14 is a regulator of $\beta 2$ integrin-dependent neutrophil slow rolling and adhesion. Nat Commun 2015; 6: 6915.

99. Qiang X, Yang WL, Wu R, et al. Cold-inducible RNA-binding protein (CIRP) triggers inflammatory responses in hemorrhagic shock and sepsis. Nat Med 2013; 19: 1489-1495.

100. Kwan J, Horsfield G, Bryant T, et al. IL-6 is a predictive biomarker for stroke associated infection and future mortality in the elderly after an ischemic stroke. Exp Gerontol 2013; 48: 960-965.

101. Castellanos M, Sobrino T, Pedraza S, et al. High plasma glutamate concentrations are associated with infarct growth in acute ischemic stroke. Neurology 2008; 71: 1862-1868.

102. Castillo J, Moro MA, Blanco M, et al. The release of tumor necrosis factor-alpha is associated with ischemic tolerance in human stroke. Ann Neurol 2003; 54: 811-819.

103. Blanco M, Castellanos M, Rodríguez-Yáñez M, et al. High blood pressure and inflammation are associated with poor prognosis in lacunar infarctions. Cerebrovasc Dis 2006; 22: 123-129.

104. Rodríguez-Yáñez M, Castellanos M, Blanco M, et al. New-onset hypertension and inflammatory response/poor outcome in acute ischemic stroke. Neurology 2006: 67; 1973-1978.

105. Oto J, Suzue A, Inui D, et al. Plasma proinflammatory and antiinflammatory cytokine and catecholamine concentrations as predictors of neurological outcome in acute stroke patients. J Anesth 2008; 22: 207-212.

106. Basic-Kes V, Simundic AM, Nikolac N, Topic E, Demarin V. Proinflammatory and anti-inflammatory cytokines in acute ischemic stroke and their relation to early neurological deficit and stroke outcome. Clin Biochem 2008; 41: 1330-1334.

107. Welsh P, Barber M, Langhorne P, Rumley A, Lowe GD, Stott DJ. Associations of inflammatory and haemostatic biomarkers with poor outcome in acute ischaemic stroke. Cerebrovasc Dis 2009: $27 ; 247-253$

108. Whiteley W, Jackson C, Lewis S, et al. Inflammatory markers and poor outcome after stroke: a prospective cohort study and systematic review of interleukin-6. PLoS Med 2009; 6: e1000145.

109. Worthmann H, Tryc AB, Goldbecker A, et al. The temporal profile of inflammatory markers and mediators in blood after acute ischemic stroke differs depending on stroke outcome. Cerebrovasc Dis 2010; 30: 85-92.

110. Brea D, Sobrino T, Rodríguez-Yáñez M, et al. Toll-like receptors 7 and 8 expression is associated with poor outcome and greater inflammatory response in acute ischemic stroke. Clin Immunol 2011; 139: 193-198.

111. Rodríguez-González R, Sobrino T, Rodríguez-Yáñez M, et al. Association between neuroserpin and molecular markers of brain damage in patients with acute ischemic stroke. J Transl Med 2011: 9: 58.

112. Domac FM, Somay G, Misirli H, Erenoglu NY. Tumor necrosis factor alpha serum levels and inflammatory response in acute ischemic stroke. Neurosciences (Riyadh) 2007; 12: 25-30.

113. Zierath D, Tanzi P, Cain K, Shibata D, Becker K. Plasma $\alpha$ melanocyte stimulating hormone predicts outcome in ischemic stroke. Stroke 2011; 42: 3415-3420.
114. Chakraborty B, Chowdhury D, Vishnoi G, Goswami B, Kishore J, Agarwal S. Interleukin-6 gene - $174 \mathrm{G} / \mathrm{C}$ promoter polymorphism predicts severity and outcome in acute ischemic stroke patients from north India. J Stroke Cerebrovasc Dis 2013: 22; 683-689.

115. Zeng L, Liu J, Wang Y, et al. Cocktail blood biomarkers: prediction of clinical outcomes in patients with acute ischemic stroke. Eur Neurol 2013: 69; 68-75.

116. Park SY, Kim J, Kim OJ, et al. Predictive value of circulating interleukin- 6 and heart-type fatty acid binding protein for three months clinical outcome in acute cerebral infarction: multiple blood markers profiling study. Crit Care 2013: 17; R45.

117. Sotgiu S, Zanda B, Marchetti B, et al. Inflammatory biomarkers in blood of patients with acute brain ischemia. Eur J Neurol 2006; 13: 505-513.

118. Chamorro A, Amaro S, Vargas M, et al. Interleukin 10, monocytes and increased risk of early infection in ischaemic stroke. J Neurol Neurosurg Psychiatry 2006; 77: 1279-1281.

119. Serena J, Blanco M, Castellanos M, et al. The prediction of malignant cerebral infarction by molecular brain barrier disruption markers. Stroke 2005; 36: 1921-1926.

120. Vila N, Filella X, Deulofeu R, Ascaso C, Abellana R, Chamorro A. Cytokine-induced inflammation and long-term stroke functional outcome. J Neurol Sci 1999; 162: 185-188.

121. Anuk T, Assayag EB, Rotstein R, et al. Prognostic implications of admission inflammatory profile in acute ischemic neurological events. Acta Neurol Scand 2002; 106: 196-199.

122. Winbeck K, Poppert H, Etgen T, Conrad B, Sander D. Prognostic relevance of early serial C-reactive protein measurements after first ischemic stroke. Stroke 2002; 33: 2459-2464.

123. Christensen H, Boysen G. C-reactive protein and white blood cell count increases in the first 24 hours after acute stroke. Cerebrovasc Dis 2004; 18: 214-219.

124. Hamidon BB, Sapiah S, Nawawi H, Raymond AA. The prognostic value of $\mathrm{C}$-reactive protein (CRP) levels in patients with acute ischaemic stroke. Med J Malaysia 2004; 59: 631-637.

125. Efstathiou SP, Tsiakou AG, Tsioulos DI, et al. Prognostic significance of plasma resistin levels in patients with atherothrombotic ischemic stroke. Clin Chim Acta 2007; 378: 78-85.

126. Vibo R, Kõrv J, Roose M, et al. Acute phase proteins and oxidised low-density lipoprotein in association with ischemic stroke subtype, severity and outcome. Free Radic Res 2007;41:282-287.

127. Geiger S, Holdenrieder S, Stieber P, et al. Nucleosomes as a new prognostic marker in early cerebral stroke. J Neurol 2007; 254: 617-623.

128. Topakian R, Strasak AM, Nussbaumer K, Haring HP, Aichner FT. Prognostic value of admission C-reactive protein in stroke patients undergoing IV thrombolysis. J Neurol 2008; 255: 1190-1196.

129. Ryu SR, Choi IS, Bian RX, Kim JH, Han JY, Lee SG. The effect of $\mathrm{C}$-reactive protein on functional outcome in ischemic stroke patients. Int J Neurosci 2009; 119: 336-344.

130. Sienkiewicz-Jarosz H, Gałecka-Wolska M, Bidziński A, et al. Predictive value of selected biochemical markers of brain damage for functional outcome in ischaemic stroke patients. Neurol Neurochir Pol 2009; 43: 126-133.

131. Song IU, Kim JS, Kim YI, Lee KS, Jeong DS, Chung SW. Relationship between high-sensitivity C-reactive protein and clinical functional outcome after acute ischemic stroke in a Korean population. Cerebrovasc Dis 2009; 28: 545-550.

132. Varoglu AO, Kuyucu M, Demir R, Acemoglu H, Can I, Akcay F. Prognostic values of lesion volume and biochemical markers in ischemic and hemorrhagic stroke: a stereological and clinical study. Int J Neurosci 2009; 119: 2206-2218.

133. Brouns R, Verkerk R, Aerts T, et al. The role of tryptophan catabolism along the kynurenine pathway in acute ischemic stroke. Neurochem Res 2010; 35: 1315-1322. 
134. Song IU, Kim YD, Kim JS, Lee KS, Chung SW. Can highsensitivity C-reactive protein and plasma homocysteine levels independently predict the prognosis of patients with functional disability after first-ever ischemic stroke? Eur Neurol 2010; 64: 304310.

135. Rajeshwar K, Kaul S, Al-Hazzani A, et al. C-reactive protein and nitric oxide levels in ischemic stroke and its subtypes: correlation with clinical outcome. Inflammation 2012; 35: 978-984.

136. Tsai NW, Lee LH, Huang CR, et al. The association of statin therapy and high-sensitivity $\mathrm{C}$-reactive protein level for predicting clinical outcome in acute non-cardioembolic ischemic stroke. Clin Chim Acta 2012; 413: 1861-1865.

137. Lai PT, Chen SY, Lee YS, Ho YP, Chiang YY, Hsu HY. Relationship between acute stroke outcome, aspirin resistance, and humoral factors. J Chin Med Assoc 2012; 75: 513-518.

138. Park HY, Jun CD, Jeon SJ, et al. Serum YKL-40 levels correlate with infarct volume, stroke severity, and functional outcome in acute ischemic stroke patients. PLoS One 2012; 7: e51722.

139. Gensicke H, Seiffge DJ, Polasek AE, et al. Long-term outcome in stroke patients treated with IV thrombolysis. Neurology 2013; 80: 919-925.

140. Tiainen M, Meretoja A, Strbian D, et al. Body temperature, blood infection parameters, and outcome of thrombolysis-treated ischemic stroke patients. Int J Stroke 2013; 8: 632-638.

141. Zhang JL, Yin CH, Zhang Y, Zhao LB, Fu HJ, Feng JC. Plasma copeptin and long-term outcomes in acute ischemic stroke. Acta Neurol Scand 2013; 128: 372-380.

142. Tu WJ, Dong X, Zhao SJ, Yang DG, Chen H. Prognostic value of plasma neuroendocrine biomarkers in patients with acute ischaemic stroke. J Neuroendocrinol 2013; 25: 771-778.

143. Abubakar SA, Okubadejo NU, Ojo OO, Oladipo O, Ojini FI, Danesi MA. Relationship between admission serum C-reactive protein and short term outcome following acute ischaemic stroke at a tertiary health institution in Nigeria. Niger J Clin Pract 2013; 16: $320-324$

144. Tu WJ, Zhao SJ, Liu TG, Yang DG, Chen H. Combination of high-sensitivity $\mathrm{C}$-reactive protein and homocysteine predicts the short-term outcomes of Chinese patients with acute ischemic stroke. Neurol Res 2013; 35: 912-921.
145. Kim SH, Lee JY, Kim do H, et al. Factors related to the initial stroke severity of posterior circulation ischemic stroke. Cerebrovasc Dis 2013; 36: 62-68.

146. Gong X, Zou X, Liu L, et al. Prognostic value of inflammatory mediators in 1-year outcome of acute ischemic stroke with middle cerebral artery stenosis. Mediators Inflamm 2013; 2013: 850714.

147. Men X, Li J, Zhang B, Zhang L, Li H, Lu Z. Homocysteine and Creactive protein associated with progression and prognosis of intracranial branch atheromatous disease. PLoS One 2013; 8: e73030.

148. Ozkan AK, Yemisci OU, Saracgil Cosar SN, Oztop P, Turhan N. Can high-sensitivity C-reactive protein and ferritin predict functional outcome in acute ischemic stroke? A prospective study. Top Stroke Rehabil 2013; 20: 528-536.

149. Taheraghdam A, Aminnejad S, Pashapour A, Rikhtegar R, Ghabili $\mathrm{K}$. Is there a correlation between hs-CRP levels and functional outcome of ischemic stroke? Pak J Med Sci 2013; 29: 166-169.

150. Karlinski M, Bembenek J, Grabska K, et al. Routine serum Creactive protein and stroke outcome after intravenous thrombolysis. Acta Neurol Scand 2014; 130: 305-311.

151. Potpara TS, Polovina MM, Djikic D, Marinkovic JM, Kocev N, Lip GY. The association of CHA2DS2-VASc score and blood biomarkers with ischemic stroke outcomes: the Belgrade stroke study. PLoS One 2014; 9: e106439.

152. Deng WJ, Shen RL, Li M, Teng JF. Relationship between procalcitonin serum levels and functional outcome in stroke patients. Cell Mol Neurobiol 2015; 35: 355-361.

153. Sezer S, Uçar F, Ulusoy EK, et al. Serum amyloid A, fetuin-A, and pentraxin-3 levels in patients with ischemic stroke: novel prognostic biomarkers? Turk J Med Sci 2014; 44: 16-23.

154. Wang C, Gao L, Zhang ZG, et al. Procalcitonin is a stronger predictor of long-term functional outcome and mortality than high-sensitivity C-reactive protein in patients with ischemic stroke. Mol Neurobiol 2016; 53: 1509-1517.

155. Richard S, Lagerstedt L, Burkhard PR, Debouverie M, Turck N, Sanchez JC. E-selectin and vascular cell adhesion molecule-1 as biomarkers of 3-month outcome in cerebrovascular diseases. J Inflamm 2015; 12: 61 